\title{
Koordinasi Pengembangan Program Kampung Keluarga Berencana di Kabupaten Bangka Barat
}

\section{Family Planning Village Development Coordination Program in West Bangka Regency}

\section{Regina1, Budiman Rusli², Candradewini ${ }^{3}$}

1,2,3 Departemen Pascasarjana Administrasi Publik, Universitas Padjadjaran, Bandung, Indonesia.

E-mail: ${ }^{1}$ reginanaw094@gmail.com

\section{ARTICLE INFO}

Keywords: coordination, program development, family planning

Kata kunci: koordinasi, pengembangan program, keluarga berencana

\section{How to cite} Regina, Rusli, B., \& Candradewini. (2020) Koordinasi Pengembangan Program Kampung Keluarga Berencana di Kabupaten Bangka Barat. JAKPP (Jurnal Analisis Kebijakan dan Pelayanan Publik), 6(1), 65-85.

\section{ABSTRACT}

Village of Family Planning or abbreviated as KB Village is one that has been implemented in Indonesia. Bangka Belitung has been in the KB Village since 2016. Precisely in West Bangka Regency currently incessantly to build a KB Village. From 2016 to 2018, West Bangka Regency already has 15 KB villages. In addition, in 2018 West Bangka Regency there is a Stunting Village in the KB Village considering that this Regency is one of the stunting sufferers with high numbers. In this study, the study used a qualitative descriptive study with case study research. To review this library using the database of Science Direct, Proquest, Goggle Scholar. Key words: "Coordination, Family Planning," This research was conducted at the Population Control and Family Planning Office of West Bangka Regency because this Office was indeed the source person in the author's research. However, there are several related departments such as the Health Office and the Provincial BKKBN because the KB Village is an activity that protects multisector. In the process of coordination for development, the KB Village discusses several important roles here, this is related to the theory used by researchers from Henry Fayol in Hasibuan's book "Human Resource Management" (2007) which discusses communication, cooperation, division of tasks, meetings and meetings. Researchers take this theory because it feels more suited to the debate raised by researchers. In this study there are conclusions that are still less effective in the process of negotiations on cooperation plans and meetings / meetings carried out by officers and devices related to the development of KB Village in West Bangka Regency.
Abstrak
Kampung Keluarga Berencana atau disingkat dengan Kampung KB adalah salah satu yang sudah diterapkan di Indonesia. Bangka Belitung sudah ada Kampung KB sejak 2016 lalu. Tepatnya di Kabupaten Bangka Barat saat ini sedang gencar-gencarnya untuk membangun Kampung KB. Dari 2016 sampai 2018 ini Kabupaten Bangka Barat sudah mempunyai 15 Kampung KB. Selain itu di tahun 2018 Kabupaten Bangka Barat ada Desa Stunting di dalam Kampung KB tersebut mengingat bahwa Kabupaten ini salah satu penderita stunting dengan angka yang tinggi. Dalam penelitian ini, peneliti menggunakan penelitian deskriptif kualitatif dengan jenis penelitian studi kasus. Untuk literature review ini menggunakan database Science Direct, Proquest, Goggle Scholar. Pada tahap awal dengan pencarian keyword : "Coordination, Family Planning" Penelitian ini dilakukan di Dinas Pengendalian Penduduk dan Keluarga Berencana Kabupaten Bangka Barat karena memang Dinas ini adalah narasumber 
dalam penelitian penulis dan melakukan wawancara di Desa Sinar Surya yang menjadi lokus penelitian. Namun, ada beberapa Dinas terkait seperti Dinas Kesehatan, dan BKKBN Provinsi karena Kampung KB ini adalah kegiatan yang bersifat multisektor. Dalam proses koordinasi untuk pengembangan Kampung KB ini melibatkan beberapa peran penting di dalamnya, hal ini mengacu pada teori yang digunakan oleh peneliti dari Henry Fayol dalam buku Hasibuan "Manajemen Sumber Daya Manusia" (2007) yakni komunikasi, kerjasama, pembagian tugas, pertemuan dan rapat. Peneliti mengambil teori ini karena dirasa lebih cocok dengan permasalahan koordinasi yang diangkat oleh peneliti. Dalam penelitian ini terdapat kesimpulan bahwa masih kurang efektifnya dalam proses koordinasi tepatnya pada bidang kerjasama dan pertemuan/rapat yang dilaksanakan oleh petugas-petugas dan perangkat terkait pengembangan Kampung KB di Kabupaten Bangka Barat.

\section{Pendahuluan}

Kampung Keluarga Berencana atau Kampung KB merupakan salah satu program yang diterapkan di Indonesia, tidak terkecuali di Provinsi Kepulauan Bangka Belitung sejak 2016 lalu. Sejak tahun 2016 sampai 2018 Kabupaten Bangka Barat sudah memiliki 15 Kampung KB. Selain itu, di tahun 2018 Kabupaten Bangka Barat ada Desa Stunting di dalam Kampung KB tersebut mengingat bahwa kabupaten ini angka Stunting nya tinggi. Seperti yang diketahui bahwa salah satu prioritas Program Nawacita Presiden Joko Widodo pada periode pertamanya (20142019) dengan fokus penggarapan pada dimensi pembangunan kesehatan serta mental atau karakter yang diintegrasikan pada program Kependudukan Keluarga Berencana dan Pembangunan Keluarga (KKBPK). Berdasarkan Undang-Undang Nomor 52 Tahun 2009 tentang Perkembangan Kependudukan dan Pembangunan Keluarga. Berdasarkan undang-undang tersebut, maka terbentuklah Program Keluarga Berencana (KB) di bawah BKKBN.

Pada pelaksanaannya, Kampung KB merupakan perwujudan dari sinergi antara beberapa kementerian terkait dari pemerintah pusat dan daerah, mitra kerja, dan pemangku kepentingan serta masyarakat setempat. Adapun tujuan dari pembentukan Kampung KB adalah untuk meningkatkan kualitas hidup masyarakat di tingkat kampung dalam rangka mewujudkan keluarga kecil berkualitas. Pembentukan Kampung KB dimulai sejak 14 Januari 2016 di Kabupaten Cirebon dan diresmikan oleh Presiden Joko Widodo. Kemudian, pada tahun 2017 jumlah Kampung KB sudah mencapai 487 atau sekitar 95\% dari target yang akan dicapai, yakni 514 Kampung KB di seluruh kabupaten/kota di Indonesia (micom, 27 September 2017, 06:30 WIB)

Kampung KB dilaksanakan pada seluruh daerah di Indonesia tidak terkecuali Provinsi Kepulauan Bangka Belitung. Pembentukan Kampung KB di Bangka Belitung sudah ada sejak tahun 2016 di Kabupaten Bangka Tengah yang sudah terbentuk 47 Kampung KB di setiap kecamatan di Bangka Belitung pada tahun 2017 lalu (Bangka Barat Dalam Angka, 2017). Komitmen Gubernur Bangka Belitung untuk meningkatkan jumlah Kampung KB dengan sangat antusias. Dalam pembentukan Kampung KB, target untuk pembentukan Kampung KB ini di tahun 2018 akan meningkat dari tahun sebelumnya. 
Tabel 1. Jumlah Kampung KB di Provinsi Kepulauan Bangka Belitung

\begin{tabular}{clcc}
\hline No. & Kabupaten/Kota & $\begin{array}{c}\text { Jumlah } \\
\text { Kecamatan }\end{array}$ & $\begin{array}{c}\text { Jumlah Kampung } \\
\text { KB }\end{array}$ \\
\hline 1 & Kota Pangkal Pinang & 7 & 7 \\
2 & Kab. Bangka Tengah & 6 & 6 \\
3 & Kab. Bangka Selatan & 8 & 8 \\
4 & Kab. Bangka Barat & 6 & 6 \\
5 & Kab. Bangka & 8 & 8 \\
6 & Belitung & 5 & 5 \\
7 & Belitung Timur & 7 & 7 \\
\hline
\end{tabular}

Sumber: BPS Provinsi Kepulauan Bangka Belitung, 2017

Kabupaten Bangka Barat adalah salah satu kabupaten yang saat ini diintervensi pemerintah untuk perkembangan Kampung KB. Untuk tingkat pencapaian tujuan khusus pembentukan Kampung KB, salah satunya bisa dilihat berdasarkan data yang dilansir dari RISKESDAS tahun 2013 bahwa kabupaten Bangka Barat adalah kabupaten yang angka stunting tertinggi di semua kabupaten di Bangka Belitung yakni mencapai 33\%. Saat ini, sudah ada 6 Kampung KB di Kabupaten Bangka Barat, yakni di kecamatan Muntok, kecamatan Simpang Teritip, kecamatan Parittiga, kecamatan Jebus, kecamatan Kelapa, dan kecamatan Tempilang. Hal ini dibuktikan dan didukung dengan data gizi buruk di Kabupaten Bangka Barat sejak 2014-2017 dapat dilihat pada tabel 2.

Tabel 2. Jumlah Bayi Lahir Bayi Berat Badan Lahir Rendah (BBLR) dan Gizi Buruk menurut Kecamatan, 2017

\begin{tabular}{lccc}
\hline Kecamatan & BBLR & $\begin{array}{c}\text { BBLR } \\
\text { Dirujuk }\end{array}$ & Gizi Buruk \\
\hline Kelapa & 27 & 14 & 1 \\
$\begin{array}{l}\text { Tempila } \\
\text { ng }\end{array}$ & 38 & 11 & - \\
Muntok & 42 & 38 & -
\end{tabular}




\begin{tabular}{lccc}
$\begin{array}{l}\text { Simpang } \\
\text { Teritip }\end{array}$ & 30 & 16 & 3 \\
Jebus & 17 & 5 & - \\
Parittiga & 28 & 13 & 2 \\
\hline Jumlah & $\mathbf{1 8 2}$ & $\mathbf{9 7}$ & $\mathbf{6}$
\end{tabular}

Sumber: Bangka Barat dalam Angka in Figure, 2017

Data di atas, dapat dilihat bahwa untuk Kabupaten Bangka Barat sendiri, tingkat kesehatan di Bangka Barat bisa dikatakan masih rendah. Hal ini juga menekankan bahwa pemerintah Kabupaten Bangka Barat harus komitmen dengan pengembangan Kampung KB di setiap Kecamatan. Namun, fakta yang terlihat bahwa belum ada kesiapan yang pasti di dalam pengembangan Kampung KB, salah satunya yakni di Desa Sinar Surya Kecamatan Tempilang.

Adapun karakteristik geografis daerah menurut desa/kelurahan bahwa kecamatan Tempilang adalah daerah daratan (Kecamatan Tempilang Dalam Angka, 2016). Kecamatan Tempilang memiliki sembilan desa, termasuk desa Sinar Surya yang menjadi objek penelitian penulis.

Tabel 3. Pertumbuhan Penduduk Menurut Kecamatan di Kabupaten Bangka Barat, 2014-2017

\begin{tabular}{lccc}
\hline \multirow{2}{*}{ Kecamatan } & \multicolumn{3}{c}{ Pertumbuhan Penduduk \% } \\
\cline { 2 - 4 } & $\mathbf{2 0 1 4 - 2 0 1 5}$ & $\mathbf{2 0 1 5 - 2 0 1 6}$ & $\mathbf{2 0 1 6 - 2 0 1 7}$ \\
\hline Kelapa & 1,33 & 1,33 & 1,27 \\
Tempilang & 1,21 & 1,22 & 1,26 \\
Muntok & 2,79 & 2,75 & 2,61 \\
Simpang Teritip & 1,69 & 1,70 & 1,59 \\
Jebus & 2,71 & 2,68 & 2,54 \\
Parittiga & 2,99 & 2,98 & 2,83 \\
\hline \multicolumn{1}{c}{ Bangka Barat } & $\mathbf{2 , 1 9}$ & $\mathbf{2 , 1 8}$ & $\mathbf{2 , 0 8}$ \\
\hline
\end{tabular}

Sumber: Kabupaten Bangka Barat dalam Angka in Figures, 2017 
Diketahui bahwa desa Sinar Surya memiliki luas $16,86 \mathrm{~km}^{2}$ dan berbatasan dengan wilayah laut. Desa Sinar Surya terpilih menjadi salah satu Kampung KB di Kabupaten Bangka Barat karena telah memenuhi unsur penilaian oleh tim dari pemerintah daerah yang bertugas dalam program KKBPK. Apabila dianalisis pada tingkat kesehatan dari beberapa daerah di Bangka Barat masih rendah. Meskipun begitu, Pemerintah Kabupaten Bangka Barat berkomitmen dalam mengembangkan Kampung KB di setiap kecamatan. Salah satu daerah yang sudah siap di Kabupaten Bangka Barat, yaitu Desa Sinar Surya Kecamatan Tempilang. Desa Sinar Surya terpilih menjadi salah satu Kampung KB di Kabupaten Bangka Barat karena telah memenuhi unsur penilaian oleh tim dari pemerintah daerah yang bertugas dalam program KKBPK. Adapun lokus dan alasan penulis memilih Desa Sinar Surya karena komunikasi dan koordinasi yang belum efektif antar multisektor dibandingkan dengan desa-desa lain yang lebih berkembang untuk Kampung KB.

Mekanisme koordinasi yang selama ini dilakukan seolah-olah berjalan sendiri-sendiri. Seharusnya yang menjadi koordinator utama dalam pengembangan Kampung KB ini, mengkoordinasikan dengan dinas terkait di antaranya yakni Dinas Pengendalian Penduduk yang mempunyai fungsi untuk melihat sejauh mana perkembangan Kampung KB di Desa Sinar Surya ini. Dinas Kesehatan yang berperan sebagai pendukung dari program kesehatan yang dilakukan dalam Kampung KB. Adapun yang dikoordinasikan di sini adalah pengembangan Kampung KB, yang dilihat dari beberapa kegiatan atau program kesehatan di antaranya Program Bina Keluarga Balita, Bina Keluarga Remaja, Bina Keluarga Lansia yang saat ini mendominasi dalam pengembangan Kampung KB. Selain itu banyak program multisektor yang tidak berjalan.

Seolah-olah di sini hanya sekedar wacana saja. Hal ini menjadi penting karena di dalam suatu organisasi tidak akan mencapai tujuan yang baik dengan komunikasi yang kurang efektif. Mekanisme koordinasi yang selama ini dilakukan seolah-olah berjalan sendiri-sendiri. Seharusnya yang menjadi koordinator utama dalam pengembangan Kampung KB ini, mengkoordinasikan dengan dinas terkait di antaranya yakni Dinas Pengendalian Penduduk yang mempunyai fungsi untuk melihat sejauh mana pertumbuhan penduduk di dalam suatu daerah tersebut. Dinas Kesehatan yang berperan sebagai pendukung dari program kesehatan yang dilakukan dalam Kampung KB. Dari hasil penelitian, penulis menemukan beberapa indikasi permasalahan dari koordinasi pengembangan Kampung $\mathrm{KB}$ ini, di antaranya :

1. Untuk pelaksanaan Kampung KB ini dirasakan masih berjalan sendiri-sendiri, seolah-olah tidak ada kerjasama antara instansi-instansi lain yang terkait dengan pengembangan Kampung KB khusus di Desa Sinar Surya Kecamatan Tempilan

2. Belum adanya kerjasama antar multi sektor terkait di dalam pengembangan Kampung KB dikarenakan masih belum terlihat efektif setiap programprogram yang memang seharusnya dilaksanakan. 
3. Pembagian tugas yang belum dilakukan dengan baik sehingga terjadilah tumpang tindih antar sektor terkait.

4. Belum terlaksananya dengan baik pertemuan dan rapat yang seharusnya dilaksanakan guna memantau kegiatan dalam Kampung KB.

Dalam hal ini seharusnya untuk menjalankan tugas, sebagai pelaksana kegiatan urusan pemerintah daerah di bidang kependudukan dan keluarga berencana, maka diperlukannya koordinasi yang baik antara koordinator dan instansi terkait berserta yang ada di lini lapangan agar kegiatan di dalam Kampung KB tersebut berjalan efektif, selain itu juga dengan sektor terkait beserta bagian lini lapangannya.

Melihat dari beberapa indikasi permasalahan di atas, maka sudah jelas terlihat bahwa dalam menyelesaikan permasalahan tersebut dibutuhkan peran dari lintas sektor terutama bidang pengendalian penduduk dan $\mathrm{KB}$, kesehatan, sosial ekonomi, pendidikan, pemukiman dan lingkungan, serta bidang lain yang sesuai dengan kebutuhan masyarakat. Perlu adanya peningkatan koordinasi yang kuat baik antar internal koordinator terkait untuk melakukan intervensi dalam mendukung pengembangan Kampung KB tersebut. Koordinasi yang kuat akan memberikan pemahaman kepada sumber daya manusia yang bertugas untuk lebih optimal menjalankan tugas pokok dan fungsi mereka apalagi saat ini Kampung KB memang sangat gencar dibangun untuk kesejahteraan masyarakat di tingkat Desa.

Peneliti melihat tidak berkembangnnya Kampung KB dalam konteks koordinasi, padahal koordinasi adalah hal yang paling penting dalam suatu organisasi supaya di dalam pembagian kerja tidak tumpang tindih. Sehingga permasalahan tersebut dirasa perlu untuk diteliti lebih lanjut khususnya di Desa Sinar Surya yang saat ini kurang berkembangnya Kampung KB karena kurang adanya sosialisasi dari pihak koordinator sendiri, dan kurangnya pemahaman tentang Kampung KB itu sendiri ditingkat lini lapangan. Selama berdirinya Kampung KB di Desa Sinar Surya yang diketahui hanya tentang kesehatan dan sistem reproduksi, padahal Kampung KB banyak program di dalamnya bukan hanya tentang kesehatan, namun sosial, ekonomi, pendidikan juga yang menjadi kegiatan yang seharusnya dilakukan.

\section{Kajian Literatur}

Dalam rangka pencapaian tujuan dalam suatu organisasi khususnya pencapaian tujuan pemerintah yang pada umumnya dituangkan dalam bentuk suatu kebijakan, tentunya membutuhkan serangkaian proses administrasi publik untuk mencapai tujuan tersebut. Dalam hal ini, manajemen memegang peranan yang penting, karena manajemen khususnya manajemen publik merupakan salah satu unsur dari administrasi publik. Tanpa adanya unsur-unsur terkait dalam rangka pencapaian tujuan maka tujuan tersebut tidak akan tercapai, begitupun jika unsur manajemen publik tidak dipenuhi maka tujuan pemerintah tidak akan tercapai. Pada unsur manajemen dapat dilihat sebagai fungsi dari tindakan yang dilakukan oleh para manajer dalam suatu organisasi, sedangkan administrasi lebih mengarah pada 
pola berfikir yang dilakukan oleh suatu organiasai dalam menjalankan atau melakukan tindakan.

Istilah koordinasi berasal dari kata inggris coordination. Kata coordinate terbentuk dari dua kata yaitu co dan ordinate yang mempunyai arti mengatur. Dengan demikian dalam istilah koordinasi sudah terkandung makna pengaturan (Ndraha, 2003;290). Koordinasi dan hubungan kerja adalah dua pengertian yang saling terkait. Dengan kata lain koordinasi hanya dapat dicapai atau terjalin bila terjadi hubungan kerja yang efektif. Hubungan kerja adalah bentuk komunikasi administrasi yang mendukung tercapainya koordinasi. Karena itu dikatakan bahwa hasil akhir dari komunikasi (hubungan kerja) ialah tercapainya koordinasi dengan cara yang berhasil guna dan berdaya guna (efektif dan efisien).

Koordinasi dan hubungan kerja merupakan pemahaman yang berbeda satu sama lain karena koordinasi hanya dapat tercapai sebaik-baiknya dengan melakukan hubungan kerja yang efektif. Hubungan kerja adalah bentuk administrasi yang membantu tercapainya koordinasi. Oleh karena itu dapat dijelaskan bahwa hasil akhir daripada komunikasi (hubungan kerja) adalah tercapainya koordinasi dengan cara yang berhasil guna dan berdaya guna. Koordinasi dimaksudkan sebagai usaha menyatukan kegiatan-kegiatan dari satuan kerja (unit-unit) organisasi, sehingga organisasi bergerak sebagai kesatuan yang bersatu guna melaksanakan seluruh tugas organisasi untuk mencapai tujuannya.

Secara normatif, koordinasi diartikan sebagai kewenangan untuk menggerakan, menyerasikan, menyelaraskan, dan menyeimbangkan kegiatankegiatan yang spesifik atau berbeda agar semuanya menjadi terarah pada tujuan tertentu. Sedangkan secara fungsional, koordinasi dilakukan guna untuk mengurangi dampak negatif spesialisasi dan mengefektifkan pembagian kerja (Ndraha, 2003;290). Bagian ini berisi teori-teori, pendekatan dan/atau konsep yang digunakan sebagai dasar berpikir dalam naskah tersebut.

Koordinasi yang dilakukan dapat terjadi di dalam satu organisasi atau antara suatu organisasi dengan organisasi lainnya, menurut Awaludin Djamin, juga mengemukakan mengenai koordinasi, yaitu Koordinasi adalah suatu usaha kerjasama antara badan, instansi, unit dalam pelaksanaan tugas-tugas tertentu sedemikian rupa, sehingga terdapat saling mengisi, saling membantu, dan saling melengkapi (Hasibuan, 2004: 86).

Seperti yang sudah dibahas di latar belakang penelitian, bahwa tujuan penelitian ini adalah sejauh mana hasil yang dicapai dalam proses koordinasi pengembangan Kampung KB di Kabupaten Bangka Barat. Sehingga untuk menemukan jawaban tujuan penelitian ini mengacu pada faktor-faktor koordinasi antar organisasi.

Henry Fayol dikutip oleh Hasibuan (2007) ada empat faktor yang melandasi dalam proses koordinasi di antaranya, komunikasi, kerjasama, pembagian tugas, serta pertemuan dan rapat.

1. Komunikasi 
Di dalam kehidupan kita selalu berhubungan dan yang juga disebut komunikasi. Dengan komunikasi kita dapat mengetahui dan akan mendapatkan informasi dan saling berhubungan atau kontak sosial. Manusia berkomunikasi untuk berbagi pengetahuan dan pengalaman. Bentuk umum komunikasi manusia termasuk bahasa sinyal, bicara, tulisan, gerakan, dan penyiaran.

Menurut Ruslan (2006 : 83) Komunikasi merupakan alat yang penting dalam fungsi public relations. Publik menaungi dan dan menghargai suatu kinerja yang baik dalam kegiatan komunikasi secara efektif dan sekaligus kinerja yang baik tersebut untuk menarik perhatian publik serta tujuan penting yang lainnya dalam public relations. Komunikasi juga bisa didefinisikan sebagai suatu proses interaksi yang mempunyai arti antara sesama manusia dengan manusia lainnya yang saling bersosialisasi.

Dalam komunikasi terdapat proses komunikasi yang memang harus dilakukan agar tidak terjadi kesalahan dalam berkomunikasi. Yang dimaksudkan transaksi di sini yaitu proses dimana komponen-komponennya saling terkait, dan bahwa para komunikatornya beraksi dan dan bereaksi sebagai suatu kesatuan dan keseluruhan.

Dari pengertian di atas dapat disimpulkan bahwa komunikasi merupakan suatu hal yang sangat penting dalam setiap kegiatan dengan tetap saling terkait satu sama lainnya.

2. Kerjasama

Kerjasama merupakan salah satu bentuk interaksi sosial. Kerjasama adalah suatu bentuk proses sosial, dimana didalamnya terdapat aktivitas tertentu yang ditunjukkan untuk mencapai tujuan bersama dengan saling membantu dan saling memahami aktivitas masing-masing. Kerjasama juga diartikan sebagai kegiatan yang di lakukan secara bersama-sama dari berbagai pihak untuk mencapai tujuan bersama. Ini adalah satu proses sosial yang paling dasar. Biasanya kerjasama melibatkan pembagian tugas, dimana setiap orang mengerjakan setiap pekerjaan yang merupakan tanggung jawabnya demi tercapainya tujuan bersama. Kerjasama adalah sesuatu yang terjadi secara alami, kelompok dapat maju dengan baik apabila ada kerjasama yang baik pula antar sesama kelompok. Kerjasama tersebut tidak dibuat-buat melainkan antar anggota kelompok memiliki rasa tanggung jawab untuk mencapai tujuan bersama. Hal ini sesuai dengan pendapat dari Elaine (2014 : 166) yang menyatakan bahwa setiap bagian kelompok saling berhubungan sedemikian rupa sehingga pengetahuan yang dipunyai seseorang akan menjadi output bagi yang lain, dan hal ini juga menjadi input bagi yang lainnya. Dapat disimpulkan bahwa kerjasama terjadi secara alami yang berupa sebuah tindakan atau sikap mau melakukan sesuatu atau kerjasama dengan orang lain dalam mencapai tujuan bersama.

3. Pembagian Tugas 
Kelompok dua atau lebih orang yang bekerja bersama secara kooperatif dan dikoordinasikan dapat mencapai hasil lebih daripada dilakukan perseorangan. Dalam suatu organisasi, tiang dasarnya adalah prinsip pembagian kerja (division of labor). Prinsip pembagian kerja ini adalah maksudnya jika suatu organisasi diharapkan untuk dapat berhasil dan efektif dengan baik dalam usaha mencapai tujuanya, maka hendaknya lakukan pembagian kerja. Pembagian kerja ini diharapkan dapat berfungsi dalam usaha mewujudkan tujuan suatu organisasi. Efektif merupakan komunikasi yang prosesnya mencapai tujuan yang direncanakan sesuai dengan biaya yang dianggarkan, waktu yang ditetapkan dan jumlah personil yang ditentukan (Effendy, 1989:14).

Untuk urusan pembagian tugas ini secara formal membuat batasan yang jelas antara organisasi dengan menggambarkan batas mengenai tugas dan tanggung jawab. Aturan tertulis membuat setiap pihak yang terlibat dalam koordinasi tahu tentang apa yang harus dilakukan oleh siapa, kapan dan bagaimana. Pembagian tugas formal tidak hanya membentuk dasar koordinasi, tetapi juga membentuk struktur koordinasi. Adanya pembagian kerja merupakan indikasi koordinasi yang lebih kuat dalam organisasi dan sebaliknya apabila tidak ada pembagian kerja mengindikasikan lemahnya koordinasi (Christensen dan Laegried, 2008:101).

4. Pertemuan dan rapat

Pertemuan atau rapat merupakan bagian dalam proses koordinasi untuk menetapkan aturan, saling menyesuaikan, berbagi informasi, membahas kebijakan dan membuat keputusan. Menurut Jacobsen (1993) koordinasi antar anggota akan terhambat jika wadah untuk bertemu tersebut tidak ada. Wadah atau arena pertemuan merupakan salah satu faktor agar proses koordinasi berjalan dengan efisien. Koordinasi dalam hal ini melibatkan proses untuk berbagi informasi, melakukan perencanaan bersama-sama, melakukan pengambilan keputusan bersama dan melakukan pertukaran staf, dan sering akan memiliki organisasi dengan struktur intraorganisasi hirarkis (Verhoest et al, 2010).

\section{Metode Penelitian}

Dalam penelitian ini penulis menggunakan pendekatan deskriptif kualitatif, karena dirasa jika melakukan penelitian dengan pendekatan deskriptif kualitatif akan memudahkan peneliti untuk melakukan wawancara mendalam dengan key informan. Peneliti juga melakukan pengumpulan data dengan wawancara mendalam dengan dari beberapa sumber terkait hal ini yakni koordinator dari Kampung KB di Kabupaten Bangka Barat, data menjadi suatu hal yang memegang peranan penting dalam penelitian yang dilakukan oleh penulis. Data yang penulis kumpulkan dalam penyusunan penelitian ini dibagi menjadi dua, antara lain primer dan sekunder. 
Data primer yang didapatkan dalam penelitian ini melalui pendekatan observasi dan wawancara. Dalam melakukan wawancara yang menjadi informan kunci adalah koordinator Kampung KB di DP2KB, Kepala Dinas DP2KB itu sendiri dan beberapa narasumber dari dinas terkait seperti Dinas Kesehatan, Dinas Sosial dan Kementrian Agama.sedangkan untuk mendapatkan data sekunder peneliti melakukan studi kepustakaan dan studi dokumentasi. Data diperoleh dari berbagai sumber, dengan menggunakan teknik pengumpulan data yang bermacam-macam dan dilakukan secara terus menerus sampai data terpenuhi. Analisis data dilakukan penulis dengan proses mencari dan menyusun secara sistematis data yang diperoleh dari hasil wawancara, catatan lapangan, dan lain-lain, dengan cara mengorganisasikan data ke dalam kategori, menjabarkan ke dalam unit-unit, melakukan sintesa, menyusun ke dalam pola, memilih data yang akan dipelajari terkait penelitian, dan membuat kesimpulan sehingga mudah dipahami oleh diri sendiri maupun orang lain.

Pengujian keabsahan data dilakukan menggunakan teknik Triangulasi Sumber dan Triangulasi Teknik. Namun, dari hasil triangulasi yang di dapat dari wawancara dengan informan kunci terdapat ketidaksesuaian dengan data yang diperoleh peneliti, kurangnya kesiapan sumber daya manusia dalam pengembangan Kampung KB di Kabupaten Bangka Barat ini khususnya di Desa Sinar Surya yang dirasa masih sangat kurang efektif dan membandingkan keadaan dengan perspektif seseorang dengan berbagai pendapat dan pandangan mengenai proses koordinasi dalam penerapan kebijakan Kampung Keluarga Berencana (KB).

\section{Hasil dan Pembahasan}

\section{Hasil Penelitian}

Dalam hal ini, proses pengembangan Kampung KB tidak bisa instan tanpa adanya sumber daya manusia yang mendukung dalam pembangunannya. Contohnya saja dalam setiap kegiatan harus ada koordinasi yang baik antar pihak masing-masing yang terkait dalam pengembangan Kampung KB ini. Di Kabupaten Bangka Barat yang memang saat ini sangat gencar dibangun Kampung KB oleh Pemerintah Daerah demi mensejahterakan masyarakat khususnya mewujudkan keluarga kecil yang berkualitas dengan berbagai program-program yang ada di dalam kegiatan Kampung KB tersebut.

Adapun yang dikoordinasikan di sini adalah pengembangan Kampung KB, yang dilihat dari beberapa kegiatan atau program seperti kesehatan di antaranya Program Bina Keluarga Balita, Bina Keluarga Remaja, Bina Keluarga Lansia yang saat ini mendominasi dalam pengembangan Kampung KB. Selain itu banyak program multisektor yang tidak berjalan seperti belum berjalannya program Bina Keluarga Balita, Bina Keluarga Remaja, Bina Keluarga Lansia jika dilihat dari program kesehatan itu sendiri, hal ini dibuktikan dari hasil wawancara dengan narasumber di Desa Sinar Surya bahwa mereka kurang memahami akan pengembangan Kampung KB itu sendiri seperti apa sehingga Kampung KB di Desa Sinar Surya tersebut tidak berjalan dengan efekti. Hal ini menjadi penting karena di 
dalam suatu organisasi tidak akan mencapai tujuan yang baik dengan komunikasi yang kurang efektif. Seharusnya SKPD KB yang menjadi koordinator utama dalam pengembangan Kampung KB ini, mengkoordinasikan dengan dinas terkait di antaranya yakni Dinas Pengendalian Penduduk yang mempunyai fungsi untuk melihat sejauh mana pertumbuhan penduduk di dalam suatu daerah tersebut.

\section{Pembahasan}

\section{Komunikasi}

Komunikasi merupakan faktor penting dalam koordinasi apapun itu kegiatannya. Karena dalam hal ini komunikasi adalah langkah awal untuk menentukan keberhasilan suatu organisasi. Untuk hal ini, komunikasi yang dilakukan dalam proses koordinasi terkait pengembangan Kampung KB, ada beberapa sektor terkait yang menjadi target komunikasi di antaranya koordinasi Kampung KB Bangka Barat menyampaikan informasi-informasi dengan baik agar tidak terjadi kesalahan atau miss komunikasi di antara petugas-petugas Kampung KB. Sejauh ini strategi yang digunakan untuk berkomunikasi dengan baik sudah dilakasanakan dengan cukup efektif.

Ukuran keberhasilan yang dicapai dalam komunikasi tersebut dilihat dari hasil yang mereka dapatkan kekompakkan mereka dalam menjalankan tugas yang sudah ditetapkan masing-masing.

Dalam proses komunikasi ini sumber daya manusia terkait yang menjadi pendukung dalam pengembangan Kampung KB tidaklah hanya semata-mata berkomunikasi belaka namun untuk penyampaian kegiatan baik di kantor maupun lini lapangan harus baik dan efektif agar tidak terjadi kesenjangan dan miskomunikasi antar pihak terkait. Pada prinsipnya komunikasi yang lancar sangatlah diperlukan antar dinas dan sektor terkait di dalam pengembangan Kampung KB ini. Mengutip wawancara informan terkait bahwa koordinator Kampung KB berkoordinasi dengan beberapa dinas terkait dan lini lapangan di Desa Sinar Surya agar pelaksanaan dalam pengembangan Kampung KB ini berjalan efektif guna kepentingan bersama.

\section{Kerjasama}

Kerjasama merupakan Kerjasama proses hubungan antara yang satu dengan yang lain yang mempunyai tugas dan tujuan yang sama. Kerjasama pada dasarnya merupakan bentuk penyelesaian tugas yang dilakukan secara bersama-sama untuk mencapai tujuan yang telah ditetapkan sebelumnya. Dalam kerjasama dibutuhkan adanya saling pengertian dari sektor terkait yang bertugas maupun antara instansi terkait. Dalam melaksanakan koordinasi pengembangan Kampung KB ini.

Untuk urusan kerjasama ini, DP2KB menjalin kerjasama dengan 12 OPD. Berdasarkan ketentuan Pasal 3 Peraturan Kepala badan Kependudukan dan Keluarga Berencana Nasional Nomor 433/PER/BI/2016 tentang Penggunaan Dana Bantuan Operasional Keluarga Berencana, salah satu prioritasnya adalah 
penyelenggaraan Kampung Keluarga Berencana. Kerjasama yang dilaksanakan bersama dengan OPD terkait antar instansi sejauh ini belum optimal, hal ini berdasarkan hasil dari wawancara dengan beberapa petugas di DP2KB, Dinas Sosial, dan Dinas Kesehatan yang mengatakan bahwa masih kurang mendukungnya kegiatan Kampung KB tersebut, karena kesibukan masing-masing organisasi. Desa Sinar Surya yang menjadi lokus penelitian sendiri mengakui bahwa untuk hal kerjasama sendiri itu hanya sebatas pemberitahuan kegiatan dari DP2KB jika ada kegiatan di daerahnya.

Dalam hubungan kerjsama ini, koordinator tidak menjalin kerjasama dengan stakeholder lainnya terkecuali dengan instansi pemerintah saja. Sebenarnya untuk urusan kerjasama ini tidak ada kendala yang besar, hanya saja di lini lapangan yang memang kurang optimal pelaksanaanya, padahal untuk SK pembentukkan Kampung KB sendiri sudah dilegalkan oleh Bupati Bangka Barat, dan sudah selayaknya untuk kerjasama pengembangan Kampung KB ini berjalan efektif. Namun, secara keseluruhan pelaksanaan tugas sudah cukup dilaksanakan dengan baik dan untuk penyuluh KB sendiri yakni ASN dari Provinsi. Terhitung dari 2016 sampai dengan 2018 sudah ada 15 Kampung KB di Kabupaten Bagka Barat, dan pada 2018 Kampung KB dikembangkan terkait dengan Desa Stunting. Karena Kabupaten Bangka Barat adalah Kabupaten tertinggi angka Stunting nya dibandingkan dengan Kabupaten lainnya.

Adapun 12 OPD terkait dalam kerjasama koordinasi Kampung KB Kabupaten Bangka Barat, di antaranya :

1. Badan Perencancaan Pembangunan, Penelitian, dan Pengembangan Daerah Kabupaten Bangka Barat.

2. Dinas Kesehatan Kabupaten Bangka Barat

3. Dinas Sosial dan Pemdes Kabupaten Bangka Barat

4. Dinas Pendidikan, Kepemudaan dan Olahraga Kabupaten Bangka Barat

5. Disdukcapil Kabupaten Bangka Barat

6. Dinas Pekerjaan Umum dan Penataan Ruang Kabupaten Bangka Barat

7. Dinas Pertanian dan Pangan Kabupaten Bangka Barat

8. Dinas Koperasi Usaha Kecil Menengah dan Perindustrian Kabupaten Bangka Barat

9. Dinas Pariwisata dan Kebudayaan Kabupaten Bangka Barat

10. Dinas Perumahan, Kawasan Pemukiman dan Perhubungan Kabupaten Bangka Barat

11. Kantor Kementerian Agama Kabupaten Bangka Barat.

Kerjasama ini juga terlihat di kesamaan tujuan dari beberapa organisasi dapat meningkatkan koordinasi antar organisasi. Sebaliknya, tujuan yang saling bertentangan dan berbeda berujung pada terhambatnya bahkan tidak akan 
terlaksananya proses koordinasi tersebut jika masih banyak pertentangan dan konflik. Menurut Ismail S. Ag dalam prakteknya, bagaimanapun koordinasi antar organisasi sering diperlukan jika dua atau lebih organisasi memiliki tujuan bersama, karena kesamaan tujuan selalu membutuhkan klarifikasi dan kekompakkan untuk kegiatan yang memang sudah dilakukan. Walaupun proses kegiatan koordinasi ini pasti ada konflik, namun proses koordinasi harus tetap dilaksanakan dan dijalankan dengan baik sesuai dengan tujuan yang sudah ditetapkan. Karena memang dalam membuat sebuah keputusan untuk proses kegiatan koordinasi tersebut tidak mengharuskan ada atau tidak adanya konflik. Di sini koordinator kampung KB bertanggung jawab penuh untuk setiap proses koordinasasi karena memang tidak mudah untuk bisa efektif melakukan tugas apalagi melihat kondisi dalam sebuah koordisasi dengan sumber daya manusia terkait agak terlalu sulit dalam mengemban tugas masing-masing. Ketika terdapat kekurangan dalam proses koordisasi, kurangnya kejelasan tujuan, interpretasi yang saling bertentangan, dan pendapatpendapat yang berbeda-beda, maka muncul ke arah yang tidak jelas atau ambigu untuk tujuan bersama dan kebijakan yang kurang terarah sehingga tidak terkoordinasi (personal interview, 15 Februari 2019)

\section{Pembagian Tugas}

Ketika dalam proses koordinasi terdapat ambiguitas peran, maka akan mengarah pada konflik antar lembaga tentang siapa yang akan melakukan apa. Adapun menurut Ibu Risma selaku koordinator koordinasi terhambat dan implementasi kebijakan mengalami kegagalan karena kurangnya arah dan terjadinya kesalahpahaman tentang siapa yang akan melakukan apa dan kapan, bersama dengan kurangnya pembagian kerja yang tepat (personal interview, 15 Februari 2019)

Pembagian tugas merupakan salah satu faktor yang fundamental dalam koordinasi, tanpa adanya pembagian tugas maka akan terjadi kebingungan dan ketidakjelasan dalam proses koordinasi pengembangan kampung KB di Kabupaten Bangka Barat. Berdasarkan wawancara empiris dengan koordinator Kampung KB yakni Ibu Risma, terlihat ketidakjelasan dalam hal pembagian tugas yakni dari sistem ketua koordinasi yang tidak berdasarkan surat legal. Hanya sekedar menjalankan perintah dari provinsi untuk mengembangkan kampung KB tanpa ada sistem tugas yang tersusun pasti untuk sumber daya manusia di organisasi tersebut (personal interview, 18 Februari 2019)

Ketidakjelasan pembagian tugas tersebut jelas berdampak pada penentuan skala prioritas yang memang harus dilakukan selama dalam proses koordinasi. Karena tidak adanya pembagian tugas yang jelas hal ini terlihat akan sangat berdampak pada peran setiap sumber daya manusia dan organisasi-organisasi terkait. Menurut Ibu Risma Untuk setiap organisasi dan dinas-dinas terkait memang sudah ditentukan, namun sumber daya manusia sendiri masih bingung untuk melakukan tugas masing-masing karena menang belum ada kejelasan yang legal untuk mengatur tugas mereka masing-masing. Hal ini juga akan membaut terjadinya tumpang tindih atau tidak berjalannya koordinasi ini sama sekali. Ketidakjelasan 
pembagian tugas ini sebenarnnya berdampak pada siapa yang bertanggung jawab atas peroses koordinasi dalam pengembangan kampung KB ini. Namun, tidak bisa dipungkiri bahwa mereka masih melakukan proses pengembangan terkait tugas dan tanggung jawab masing-masing (personal interview, 18 Februari 2019)

Pihak dari Dinas Pengendalian Penduduk dan Keluarga Berencana Kabupaten Bangka Barat mengatakan akan memberi dan mengadakan pelatihan kepada sumber daya manusia terkait agar lebih siap dalam melakukan tugas mereka masing-masing. Hal ini juga berlaku untuk sumber daya manusia yang ada di setiap kecamatan yang sudah ditetapkan sebagai kampung KB agar memudahkan mereka dalam mendukung dan melaksanakan kegiatan kampung KB serta merta meningkatkan kesehatan reproduksi yang pasti di tingkat desa, kecamatan, dan kabupaten.

Tabel 4. Daftar Pembagian Tugas Antar Instansi

No. Instansi Ranah/Tupoksi

1 Dinas Pengendalian Penduduk $\mathrm{KB}, \mathrm{PP}$, dan PA

2 Badan Perencanaan

Pembangunan, Penelitian, dan

Pengembangan Daerah

3 Dinas Kesehatan

4 Dinas Sosial dan Pemdes

5 Dinas Pendidikan, Kepemudaan dan Olahraga

6 Disdukcapil

7 Dinas Pekerjaan Umum dan Penataan Ruang

8 Dinas Pertanian dan Pangan

9 Dinas Koperasi Usaha Kecil Menengah dan Perindustrian
Koordinator Pengembangan

Kampung KB

Kependudukan dan Keluarga

Berencana

Pelayanan KB, Kesehatan

Masyarakat

Mensejahterakan masyarakat

Pengentasan buta huruf, mengurangi angka putus sekolah

Kependudukan dan Keluarga

Berencana

Pembangunan jalan, perbaikan jembatan, menaggulangi sampah, dll.

Meningkatkan pertanian dan pangan di setiap Kecamatan

Meningkatkan UKM di tingkat masyarakat 
Dinas Pariwisata dan

Kebudayaan

11

Dinas Perumahan, Kawasan

Pemukiman dan Perhubungan

12

\section{Kantor Kementrian Agama}

Meningkatkan adat dan budaya di setiap Kecamatan

Membantu dalam meningkatkan keluarga kecil berkualitas

Mensosialisasikan pendewasaaan usia pernikahan.

Sumber : Arsip Dinas Pengendalian Penduduk, KB, PP, dan PA Kabupaten Bangka Barat, 2017

\section{Pertemuan dan Rapat}

Rapat adalah suatu pertemuan organisasi yang resmi dengan tata tertib yang agak mengikat. Sehingga keputusan-keputusan yang ditetapkan dalam rapat tersebut bersifat mengikat. Pertemuan melalui rapat antara instansi terkait berfungsi sebagai sarana membahas dan memecahkan masalah yang dihadapi dan usulanusulan dari tim dapat disampaikan sebagai bahan untuk mempertimbangkan bagi tim dalam menjalankan tugas. Rapat juga berguna agar hubungan antara anggota tim terpadu tercipta hubungan yang terkait dan jelas secara keseluruhan yang dapat mendorong terjadinya koordinasi yang baik. Selain itu dengan adanya pertemuan melalui rapat-rapat juga dapat mengevaluasi kegiatan yang telah dilaksanakan.

Pengembangan Kampung KB sendiri tidak lepas dari adanya pertemuanpertemuan dan rapat antar instansi pemerintahan maupun multi sektor lainnya. Pertemuan dan rapat memang seharusnya dilakukan rutin baik itu mingguan atau bulanan. Dari hasil wawancara dengan Ibu Desi perwakilan koordinator Kampung KB Kabupate Bangka Barat bahwa rapat tidak dilakukan secara rutin karena memang kegiatan rapat tersebut banyak pihak-pihak yang susah hadir. Wadah atau arena pertemuan merupakan salah satu faktor agar proses koordinasi berjalan dengan efisien (personal interview, 19 Februari 2019). Koordinasi dalam hal ini melibatkan proses untuk berbagi informasi, melakukan perencanaan Bersama-sama, melakukan pengambilan keputusan bersama dan melakukan pertukaran staf, dan sering akan memiliki organisasi dengan struktur intra-organisasi hirarkis (Verhoest et al, 2007).

Dengan adanya pertemuan dan rapat, akan memudahkan proses koordinasi dan semua proses koordinasi tersebut dapat didokumentasikan dengan baik di pertemuan dan rapat tersebut. Ketersediaan tempat atau wadah pertemuan memang membutuhkan anggaran yang harus disesuaikan dengan kebutuhan sumber daya manusia yang hadir serta harus dialokasikan ketika arena pertemuan tersebut dikhususkan hanya untuk koordinasi saja. Oleh karena itu, secara empiris arena pertemuan tersebut sifatnya masih kondisional dan tidak menetap.

Menurut Ibu Desi selaku perwakilan koordinator yakni untuk pertemuan dan rapat dalam proses koordinasi pengembangan kampung KB ini berdasarkan hasil wawancara dengan Kepala Dinas Pengendalian Pendudukan dan Keluarga Berencana Kabupaten Bangka Barat beliau mengatakan bahwa untuk tempat atau wadah pertemuan tersebut secara umum tidak ada tempat khusus, namun biasanya 
dilakukan di gedung pemerintah daearah di tingkat kabupaten, itupun jika pertemuan dilakukan sebulan sekali, namun untuk pertemuan yang dilalukan di tingkat kecamatan itu random, bisa dilakukan di kecamatan mana saja karena memang kegiatan pertemuan dan rapat ini tidak terlalu difokuskan, sumber daya manusia dalam proses koordinasi ini hanya memokuskan pada pengembangan kampung KB saja, sehingga hal-hal seperti pertemuan dan rapat ini sering dilupakan karena jarang dilakukan (personal interview, 19 Februari 2019).

Mengapa penulis mengatakan hal ini jarang dilakukan, karena berdasarkan hasil dari wawancara dengan koordinator pengembangan kampung $\mathrm{KB}$, beliau mengatakan bahwa ketika akan dilakukannya pertemuan dan rapat antar dinas dan organsasi terkait susah untuk mengumpulkan dan mengkoordinasikan dengan pihak tertentu, hal ini terjadi sudah jelas terlihat karena memang kurangnya koordinasi mereka dengan pihak-pihak terkait dan kurangnya kesiapan dalam proses pelaksanaan kegiatan tersebut.

Proses koordinasi dalam hal ini bersifat tentative atau tidak tetap. Karena pertemuan dan rapat ini memang bisa dilakukan dimana saja sesuai dengan apa yang menang harus dibahas dalam rapat tersebut, jika memang hanya yang terlibat tidak banyak sumber daya manusia maka hal ini akan dilakukan biasanya di Dinas Pengendalian Penduduk dan Keluarga Berencana ini sendiri. Berdasarkan wawancara dengan Kepala Dinas Pengendalian Penduduk dan Keluarga Berencana Kabupaten Bangka Barat bahwa pertemuan dan rapat ini tidak dilakukan rutin, mereka hanya memfokuskan pada kegiatan pengembangan kampung KB nya saja atau bisa dikatakan masih bersifat kondisional. Hal ini tidak terikat dan bisa dilakukan dimana saja misalnya seperti di Dinas Pengendalian Penduduk dan Keluarga Berencana, di Dinas Kesehatan, Dinas Sosial, dan kecamatan-kecamatan yang sudah ditetapkan sebagai kampung KB di Kabupaten Bangka Barat.

Kegiatan ini sama halnya dengan pertemuan dan rapat jika membahas kegiatan koordinasi antar pihak kabupaten dan provinsi, jika ada kegiatan yang mengharuskan bertemunya pihak BKKBN dari provinsi ke Kabupaten, maka ini biasa dilakukan di Dinas Pengendalian Penduduk dan Keluarga Berencana, karena memang dinas tersebut menjadi wadah dalam pelaksanaan dan pengembangan kampung KB di Bangka Barat. Kegiatan ini biasanya juga jarang-jarang dilakukan ke setiap kecamatan-kecamatan, karena dari pihak BKKBN hanya sekedar datang melihat dan mengawasi dalam perkembangan kampung KB saja. Tidak tersedianya tempat atau wadah yang pasti untuk pertemuan dan rapat dalam proses koordinasi ini dan optimalisasi sumber daya manusia disebabkan karena ketidaksiapan mereka dan proses koordinasi yang tidak terikat satu sama lain mulai dari perencanaan sampai proses pembagian tugas masing-masing. Hal ini seharusnya sangat penting dilakukan, karena ini menjadi acuan utama untuk keberhasilan dalam sebuah proses koordinasi.

\section{Kesimpulan}

Berdasarkan hasil penelitian yang dibuat oleh penulis tentang koordinasi dalam pengembangan Kampung KB di Kabupaten Bangka Barat maka peneliti memperoleh kesimpulan yang memuat faktor-faktor dalam proses koordinasi di 
antaranya komunikasi, kerjasama, pembagian tugas, pertemuan dan rapat. Proses koordinasi dalam pengembangan kampung KB di Kabupaten Bangka Barat belum berjalan dengan optimal. Pada dasarnya semua sistem dalam kerja terutama di Dinas Pengendalian Penduduk dan Keluarga Berencana sudah tersusun sesuai dengan SOP (Standar Operasional Prosedur), namun pada kenyataannya masih belum efektif dijalankan dikarenakan beberapa hal yang membuat kegiatan ini belum berjalan dengan optimal.

Selain itu dari beberapa indikasi permasalahan yang sudah dibahas di atas, mulai dari komunikasi yang sering menjadi miskomunikasi, kerjasama yang seharusnya dilaksanakan namun tetap saja tidak berjalan dengan efektif, pembagian tugas yang pada dasarnya sudah dibagi namun masih saja melenceng dari setiap bidang masing-masing, serta pertemuan dan rapat yang sangat sering terjadi permasalahan, karena rapat yang seharusnya dilaksanakan rutin namun pada kenyataannya sangat jarang dilakukan. Selain itu rapat ini dilaksanakan tidak di tempat yang memang seharusnya menjadi pertemuan, namun jika dilakukan rapat biasanya dilakukan di tempat yang bisa dikatakan kurang memadai. Permasalahan ini karena memang saat ini, untuk kegiatan Kampung KB sendiri dijalankan mulai 2017, sehingga untuk persiapannya pasti sangat memerlukan waktu sehingga semuanya bisa siap dijalankan.

Dari sumber daya manusia yang ditunjuk langsung tanpa melalui SK Penetapan koordinator sendiri untuk Kabupaten Bangka Barat, sehingga Dinas Pengendalian Penduduk dan Keluarga Berencana Kabupaten Bangka Barat menjadi rumah atau wadah organisasi yang sangat dinomor satukan di dalam kegiatan ini. Untuk instansi-instansi yang lain seperti Dinas Kesehatan, Disdukcapil, Dinas Sosial, Dinas Pemuda dan Olahraga, dan beberapa dinas terkait hanya sekedar membantu untuk ikut andil dalam setiap kegiatan di dalam koordinasi pengembangan kampung KB sesuai dengan bidangnya masing-masing.

Tujuan bersama dalam koordinasi pengembangan kampung $\mathrm{KB}$ di Kabupaten ini sendiri merujuk pada agar bagaimana agar kampung KB ini bisa berkembang pesat di setiap Kecamatan dan desa-desa yang sudah disahkan menjadi kampung KB sehingga bisa mewujudkan keluarga kecil berkualitas. Namun bukan hanya itu saja, tujuan dari koordinasi ini agar mempersiapkan sumber daya manusia yang berkualitas yakni bagaimana menjalin komunikasi yang baik dengan berbagai instansi, menjalin kerjasama agar terbantunya setiap kegiatan yang positif terkait dengan semua kegiatan yang berhubungan dengan program-program yang ada di dalam kampung KB, bagaimana memberikan tugas sesuai dengan jabatan dan posisi yang sudah ditentukan kepada masing-masing sumber daya manusia, menjalin silaturahmi dengan adanya pertemuan dan rapat dengan berbagai instansi-instansi terkait. Selain itu, harus adanya sikap optimis dan yakin dari setiap sumber daya manusia agar terciptanya tujuan yang efektif dan efisien sesuai dengan yang sudah ditentukan di awal. 


\section{Daftar Pustaka}

BKKBN, Pembangunan Keluarga Sejahtera dalam Rangka Peningkatan Penanggulangan Kemiskinan (Jakarta: BKKBN, 1996)

Bouckaert, Geert, B.Guy Peter dan Verhoest. 2010. The Coordination of Public Sector Organization. New York: Palgrave Macmillan.

Cristensen, T and Laegreid, P., 2008. The challenge of coordination in central government organization: the Norwegian case. Public organization review.

Daft, Richard L. 2010. Manajemen. Jakarta : Salemba Empat Handoko, T. Hani. 2003. Manajemen Sumber Daya Manusia. Bandung : Salemba Empat

Edward III, C. George, 1980. Implementing Public Policy. Congressional. Quarterly INC, Washington DC.

Grindle, 1981. Politic and Policy Implementation in the Third World. Princeton University Press, New Jersey.

Handayaningrat, Soewarno. 2002. Pengantar Studi Ilmu Administrasi dan Manajemen. Jakarta

Hasibuan, Malayu S.P. 2006. Manajemen Sumber Daya Manusia. Jakarta : Bumi Aksara

Bumi Aksara

Herujito, Yayat M. 2001. Dasar-Dasar Manajemen. Jakarta : PT. Bumi Aksara

http://en.wikipedia.org/wiki/Family_planning

Inu kencana, Djamaludin Tandjung, Supardan Modeong. Ilmu Administrasi Publik. (Jakarta : PT. Rineka Cipta, 1999) Hlm 87.

Johnson, Elaine B. 2014. Contextual Tecnig and Learning. Bandung : Mizan

JUKNIS Kampung KB Badan Perwakilan BKKBN Provinsi Kepulauan Bangka Belitung

Kabupaten Bangka Barat Dalam Angka in Figures 2017

Kecamatan Tempilang Dalam Angka 2017

Koontz Harold dan O'donel Cyrill. 2000. Prinsip-Prinsip Manajemen. Jakarta : Bhatara

Manullang, M. 2008. Dasar-Dasar Manajemen. Yogyakarta: Gajah Mada University Press Mochtar, Rustam. 1998. Sinopsis Obstetry Jilid I. Jakarta : EGC

Mardiya. Memahami Arah Program KKBPK Tahun 2015-2019. Kulon Progo.

Mazmanian, Daniel and Sabatier, Paul, 1983. Implementation and Public Policy Foresman and Company, USA. 
Moekijat. Koordinasi (Suatu Tinjauan Teori). (Bandung: Mandar Maju, 1994), hlm 57.

Moleong, J. Lext. 2011. Metodologi Penelitian Kualitatif. Remaja Rosdakarya, Bandung.

Ndraha, Taliziduhun. 2003. Kybernology : Ilmu Pemerintahan. Jakarta : Rineka Cipta Syafri, Wirman H. 2012. Studi Tentang Administrasi Publik. Jakarta : Erlangga

Nirwan. 2013. Analisis Implementasi Kebijakan Program Daerah Pemberdayaan Masyarakat (PDPM) Kecamatan Palu Timur di Kota Palu. Palu: e-Jurnal Katalogis. Vol 1, No. 7.

Nur Fajriana. 2014. Koordinasi Kepala Desa dalam Pembangunan Infrastruktur di Desa Suatang Keteban Kecamatan Pasir Belengkong Kabupaten Paser. Jurusan Ilmu Pemerintahan Fakultas Ilmu Sosial dan Ilmu Politik Universitas Mulawarman.

Onong Uchjana, Effendy. 1986. Human Relations dan Public Relations dalam Manajemen. Penerbit Alumni, Bandung.

Pasolong, Harbani. 2011. Teori Administrasi Publik. Bandung: Alfabeta.

Peraturan Pemerintah Nomor 38 Tahun 2007 Tentang Urusan Pemerintah Pusat dan Pemerintah Daerah

Peraturan Pemerintah Nomor 41 Tahun 2007 Tentang Organisasi Perangkat Daerah Berkaitan Dengan Program KB

Peraturan Presiden Nomor 62 Tahun 2010 Tentang Badan Kependudukan dan Keluarga Berencana Nasional

Program KKBPK dalam SDKI 2017

Pusat Pendidikan dan Latihan BKKBN, Keluarga Berencana dan Hubungannya dengan Kesejahteraan Keluarga (Jakarta: BKKBN, 1980).

Republik Indonesia, 1992. Undang-undang Nomor 10 Tahun 1992 tentang Perkembangan Kependudukan dan Pembangunan Keluarga Sejahtera.

Republik Indonesia, 2004. Undang-undang Nomor 25 Tahun 2004 tentang Sistem Perencanaan Pembangunan Nasional.

Republik Indonesia, 2009. Undang-undang Nomor 52 Tahun 2009 tentang Perkembangan Kependudukan dan Pembangunan Keluarga.

Republik Indonesia, 2014. Undang-undang Nomor 23 tahun 2014 tentang Pemerintah Daerah.

Ruslan, Rosady. 2006. Metode Penelitian Public Relations dan Komunikasi. Jakarta: PT. Raja Grafindo Persada.

Rusli, Budiman. 2015. Kebijakan Publik: Membangun Pelayanan Publik yang Responsif. Bandung : CV. ADOYA Mitra Sejahtera 
Shiffman, Jeremy. 2002. The Construction Of Community Participation: Village Family Planning Groups And The Indonesian State. Sosial Science \& Medicine Journal, Department of Public Administration, Syracuse University Maxwell School of Citizenship and Public Affairs Alan K. Campbell Public Affairs Institute, 306 Eggers Hall Syracuse: New York.

Siagian, Sondang, 2006. Filsafat Administrasi. Bumi Aksara, Jakarta.

Sotarto, Dasar-Dasar Organisasi, cet 16, (Yogyakarta : Gadjah Mada University Press, 1993), halaman 74.

Statistik Kesejahteraan Rakyat Kabupaten Bangka Barat 2017.

Sugiyono, 2002. Metode Penelitian Administrasi. Alfabeta, Bandung.

Suratun, dkk. 2008. Pelayanan Keluaraga Berencana \& Pelayanan Kontrasepsi. Jakarta : Trans Info Media

Sutarto. 2002. Dasar-Dasar Organisasi. Yogyakarta : Gajah Mada Universitas Press

Sutarto. 2006. Dasar-Dasar Organisasi. Yogyakarta : Gajah Mada Universitas Press Tangkilisan. 2004. Kebijakan dan Manajemen Otonomi Daerah. Yogyakarta: Lukman Offset

Syamsi S.U, Ibnu. 2001. Pokok-Pokok Organisasi dan Manajemen. Jakarta : Rineka Cipta Sugiyono. 2006. Metode Penelitian Administrasi. Bandung : Alfabeta

Syamsi S.U, Ibnu. 2013. Metode Penelitian Pendidikan Pendekatan Kuantitatif, Kualitatif, dan R\&D. Bandung : Alfabeta

The Role of Family Planning in the Reduction of Poverty By Arthur A. Campbell - Journal of Marriage and Family, Vol. 30, No. 2, Family Planning and Fertility Control (May, 1968), pp. 236-245

Undang-Undang Nomor 23 Tahun 2014 Tentang Pemerintah Daerah

Undang-Undang Nomor 52 Tahun 2009 Tentang Perkembangan Kependudukan dan Pembangunan Keluarga

Volkery, Axel. Jacob, Klaus, Begha, Francois. Coordination, Challenge and innovation in National Sustainable Development Strategies. Greening of Policies: Inter-linkages and Policy Integration 2004

White, D. Leonard. 2000. Introduction Studi of Public Administration. Jakarta : Intermedia

Wiludjeng, Sri. 2007. Pengantar Manajemen. Yogyakarta : Graha Ilmu

Wursanto. 2003. Dasar-Dasar Ilmu Organisasi. Yogyakarta : Andy

Wursanto. 2016. Integrasi Kampung KB Bersama Mitra Kerja. Jakarta : BKKBN Brantas. 2009. Dasar-Dasar Manajemen. Bandung : Alfabeta 
Volume 6 No. 1, Juni 2020

pISSN: 2460-6162. eISSN: 2527-6476 